\title{
RePLITO
}

\section{Affective Colonization as Minority Management}

\author{
A. Dirk Moses ${ }^{1}$ \\ ${ }^{1}$ University of North Carolina at Chapel Hill
}

Published on: Feb 04, 2022

DOI: $10.21428 / f 4 c 6 e 600.866 f 046 e$

License: Creative Commons Attribution 4.0 International License (CC-BY 4.0). 


\section{Introduction}

Minority management has become an imperative for the German state especially after changes in the citizenship law in 2000,9/11, and the entry of nearly one million mainly Syrian refugees in 2015. Although Muslims comprise only between $6.4 \%$ and $6.7 \%$ of the population - ca. 5.3 to 5.6 millions - concern about "imported antisemitism" is particularly acute among authorities and in the press.

This anxiety was played out in public in the saga of the German-Palestinian journalist and physician, Nemi El-Hassan, in the northern autumn of 2021. On 10 September 2021, the WDR public broadcaster announced that El-Hassan would host its popular television science show, Quarks. Yet it suspended the offer four days later pending an investigation into the accusation of the rightwing tabloid newspaper, Bild-Zeitung, published on 13 September, that she was an antisemite and Islamist. After further investigation, WDR withdrew the offer officially in early November. How best to understand the modalities of minority management to which El-Hassan was subject? Extant approaches of "ethnic caging," demonization and delegitimization partially capture them. So does the notion of "affective governance" that scholars have identified in colonial rule, which can also be directed to domestic migrant communities. But the case shows that official policy goes further in Germany and can be better understood as affective colonization. In Germany, Palestinians are bidden to feel and experience the world like the German political class if they want public employment or be active in public life: adopting its interpretative frame of reference in relation to the country's politics and history. In the following, I briefly elaborate this German frame, then reconstruct its confrontation with Nemi El-Hassan via the German media, before theorizing how affective colonization operated in this case.

\section{The German Frame}

The German frame is the product of the moral refoundation of the republic that took place between 1985, with President Richard von Weizsäcker's momentous speech on World War II and German identity, and 2005 with the opening of the Memorial to the Murdered Jews of Europe in Berlin. In my book, German Intellectuals and the Nazi Past (Moses, 2007), I identified a new German subjectivity that drove this moral revolution: Shocked by the Holocaust in which their Nazi parents and grandparents were implicated, some Germans supplanted the national orientation of most Germans by identifying with their Jewish victims rather than their own families who had suffered from Allied bombing or been expelled from East-Central Europe after the war. The 
"Non-German German" was embodied by the philosopher Jürgen Habermas, a "45er," born in 1929, but was generalized by the "68er" generation in confrontations with their parents and the West German state from the 1960s.

By the 1980s, however, the 68ers failed utopianism was channelled into opposition to Helmut Kohl's new conservative government that was intent of reviving traditional German identity. Now the republic that they had decried as corrupted by Nazism and capitalism needed defending from reaction. Anti-Zionism was gradually supplanted by civil society groups engaged in local Holocaust memory activism. What remained a minority position well into the 1980s became official memory by the late 1990s as members of the 1960s student movement generation constituted a new Green-SPD government (1998-2005). Having marched through the institutions over the decades, the former "non-German Germans" incorporated the fate of Germany's Jews into their core identities as redeemed Germans. This frame led to the commendable concern for remembering the Holocaust and protecting Jewish life in Germany that has earned international praise.

This victim identification extended to Israel as the land of the survivors and sanctuary for future refugees. Such unconditional identification entails blindness to the nature of Israeli rule over Palestinians in Israel and the occupied territories. Reports by Palestinian, Israeli, and international human rights groups documenting systematic human rights abuses and the international crimes of apartheid and persecution are either ignored or denounced as antisemitic. In practice, that means disciplining public speech about Israel and Palestine, admonishing non-Zionist Jews and even Jews who think of themselves as Zionists but who are critical of Israeli policies. Whereas the Zionist frame of exilic trauma and the consequent Israeli law of return are honoured, non-Zionist ones are delegitimized, including the Palestinian claimed right of return. Because the Palestinian right of self-determination is thought to contradict the Jewish one, German commentators routinely call it antisemitic.

The Deutschlandfunk radio journalist Sebastian Engelbrecht expressed the official view in defending Nemi El-Hassan's sacking thus:

It has to be made clear to her [El-Hassan] that in Germany she has to compromise her right to just be who she is, in the framework of diversity, so to speak ... If she is the presenter of a public service broadcaster, then she cannot simply say "I am who I am," but must submit to this social consensus that ultimately led to what we call the Basic Law. 
Consequently, she needed to remember that "we live in Germany and not in Palestine." Although Engelbrecht was firmly contradicted by two colleagues who accused him of setting political orthodoxy tests, his view prevailed at WDR and in German politics, and was supported also by Josef Schuster, head of the Central Council of Jews in Germany.

\section{“Extremely Dangerous and Limited”: Nemi el-Hassan and the German Media}

Nemi El-Hassan's public ordeal commenced when the Bild-Zeitung was supplied with video footage of her participation in the so-called Al-Quds demonstration in Berlin 2014 by a far-right blogger. Consistently using images of El-Hassan in the hijab she once wore, Bild-Zeitung and the mainstream media (apart from the Berliner Zeitung) depicted her as a dangerous fanatic because she had frequented the Blue Mosque in Hamburg, which has official ties to Iran (but which also was the cooperation partner of the city of Hamburg in the framework of a "Staatsvertrag" [state contract]. In addition, she was accused of having once trivialized the notion of "Jihad." Like the rest of the German press, it also depicted the Al-Quds demonstration as a wildly antisemitic affair, although witnesses report that its organizers wanted to focus protest on the Israeli bombing of Gaza - during which over 2100 Palestinians and 73 Israelis were killed taking place at the time. In the event, the public narrative ignored Israeli alleged war crimes and crimes against humanity that are now subject to International Criminal Court investigation.

Also ignored was El-Hassan's successful television career and prize-winning record of journalistic engagement against racism. Some of that record was made public when she submitted to interview with Der Spiegel to tell her side of the story. The resulting publication in mid-September reads more like an interrogation, with the magazine demanding answers regarding her position on Israel and Islam, and doubting whether they were sincere: wasn't she now making the right noises to retain her job, they asked her? Conscious of her accommodating role as a "minor citizen," as Sultan Doughan explains the position of migrants vis-à-vis white innocence vs. migrant shame in her contribution to this series, El-Hassan not only apologized for her participation in the 2014 demonstration, but also for being unable to rule out having "said anti-Zionist things that serve hostility to Israel." Concluding ruefully, she said she was "ashamed for this time" in her life.

Soon after, on 20 September, 385 academics, artists, and intellectuals condemned the vilification campaign in a widely discussed petition. Seemingly sensing that it had not finished her off, Bild-Zeitung now combed El-Hassan's Instagram account for incriminating evidence. This they published on 21 September in the form of her "likes" 
of posts by the Jewish Voices for Peace (JVP) organization on the escape of six Palestinians from a high-security prison in Israel and on its call to boycott goods from the occupied Palestinian territories.

In a meeting with El-Hassan, WDR pursued the Der Spiegel line of questioning about her faith and stance on Israel: did she pray and fast and, if so, how often? What about her family? Do she and her family ruminate on the flight of Palestinians that attended the foundation of Israel? Why did she not write about Muslim antisemitism? WDR also scrutinized her social media activity. El-Hassan's conversion to German affects was being doubted. Queried about such intrusive questions that have no bearing on hosting a science show and that are difficult to reconcile with employment law, WDR declared that it needed to ascertain whether El-Hassan was an Islamist and/or antisemite.

After the revelation of her Instagram "likes," on 2 November, WDR withdrew its offer despite the appeal of the former Israeli ambassador to Germany, Avi Primor, and the Israeli historian, Moshe Zimmermann, who argued on 18 October that the posts she had "liked" pointed to the futility of occupation rather than celebrating the prisoners. Yet that was not the end of the matter. Understanding that her conversion had failed to convince WDR and most of the German press, El-Hassan published a defiant article in the Berliner Zeitung under the title of "Ich bin Palästinenserin - deal with it!" (in English in Forward). Now abandoning the official German frame, she related the traumatic experiences of her Palestinian family in Lebanon at the hands of Israeli troops. And she explained how her generation (she was born in Germany in 1993) observed its parents' silence about Israeli human rights violations because they understood that their presence in Germany represented a "provocation." By contrast, El-Hassan would not be cowed. "I refuse to deny my identity," she declared. "I am and always will be Palestinian, whether the German public likes it or not." She also understood that her treatment indicated that she was considered ontologically dangerous for Germans: "an antisemite by birth." Why? Because "German guilt has been systematically outsourced to the Palestinians, the Arabs, the Muslims - the perceived sources of this alleged new antisemitism."

In feeling freer than her parents to live out her identity, El-Hassan was articulating a new form of German modernity: one that allowed layered identities rather than having to efface migration backgrounds in a zero-sum replacement logic. Her critics affected to be unimpressed. The Süddeutsche Zeitung and its journalist Laura Hertreiter sided with WDR. She mused that El-Hassan's article was just "a big resignation letter" that, in telling her family's story, unintentionally legitimized prejudices about Israel and 
Jews. Her other misstep, Hertreiter concluded, was misunderstanding that journalists are not activists, and thus must appreciate complexity beyond their own perspective. The Deutschlandfunk radio journalist Sebastian Engelbrecht went further, saying that "ein Palästinensisches mir san mir [Bavarian for "we are we"] ist äusserst gefährlich und beschränkt" ("a Palestinian 'we are who we are' is very dangerous and limited") and thus unacceptable for a German public broadcaster.

Having understood these rules of the game, some Muslim actors now offered their services to state authorities to socialize Muslim youth into German culture. Like Hertreiter and Engelbrecht, they accused her of stubbornly cleaving to her Palestinian particularity at the expense of the German universality that they have supposedly achieved. They all seem to be oblivious to the fact that the vaunted German universality is constituted by asymmetrical empathy towards Zionist sensibilities that they believe the burden of German history requires.

\section{Affective Colonization}

How to explain El-Hassan's experience? We are dealing not only with "ethnic caging," a concept that the anthropologist Ghassan Hage coined to indicate the limits of tolerated minority assertion and size. Liberals and conservatives are seeking to do more than encage them. The governing of "native" affects has long been recognized as integral to colonial rule. The anthropologist Ann Laura Stoler called colonial rule "affective states."

[T]he state's assessment of the intensity of "feelings," "attachments," and senses of belonging - that prompted loyalties to race over family, or family over state - were not metaphors for something else but instrumental as "dense transfer points of power" in themselves .... Such concerns informed virtually every aspect of social policy, political calibrations, and the tone and tenor of the archives produced about them (Stoler 2007, 7).

The anthropologist Nitzan Shoshan similarly deploys "affective governance" to capture the state's "management of hate" in the German far-right youth milieux. By affects he means his subjects' "not entirely conscious and explicit attachments and investments" in addition to their emotions. This invocation of the "affective turn" in the cultural sciences usefully draws attention to the non-rational domain - how individual impulses and emotions are social and historical products of collective experience - at play in the El-Hassan case. These materially embedded and embodied affects then produce specific frames or structures of experience. The sociologist Erving Goffman invoked 
frames as "a limited set of basic reinterpretation schemas" that integrate "the whole set [of experiences] ... to the 'same' event" (Goffman, 1981: 68).

For Palestinians, the frame is exilic trauma due to the colonization of, and expulsion, from their homeland. It exceeds the punctual event of the 1948 Nakba ("catastrophe") because it is an ongoing. condition of exile and persecution. As an interpretative frame, the pulse of that traumatic history is embodied and embedded experience. It inheres in the circumstances that took El-Hassan's parents from their homeland to Lebanon and then, refugees again, to Germany.

The El-Hassan case is one example of how Palestinian affects are subject to German discipline and governance, whether by the state or public opinion. However, the German pre-occupation with Palestinian affects and its frame goes further than governance. For the German political class is seeking to replace the Palestinian structure of experience altogether with a German one that is oblivious to the situation in Israel and Palestinian territories. That is why I think the appropriate term to describe this effort is affective colonization. This term takes the notion of replacement and permanent occupation from the field of Settler Colonial Studies, which posits that settler colonialism does not exploit natives' labour but takes their land and eliminates the superfluous population in one way or another. In her new book on Palestinian subjectivity in Germany and Switzerland, the Middle East Studies scholar Sarah El Bulbeisi similarly describes how the "moral occupation" of Palestinians in the diaspora resulted in the dissolution of the self, feelings of invisibility, absence, even guilt inwardly, and self-negation outwardly: in short, into a traumatic existence - especially among first-generation Palestinians - since the colonial experience in historical Palestine was continued and repeated on a symbolic level through moral occupation in Germany. But whereas the first generation remains passive in its trauma of race (Frantz Fanon) in order to survive, the second generation starts to transform it into agency and reclaims the socially rejected identity and history, replacing self-denial with politics of visibility.

The German policy of replacing Palestinian affects with German ones then represents a domestic application of the colonial governance of "natives," who Westerners regarded as emotionally given to fanaticism - especially Muslims and, earlier, also Jewish revolutionaries. Ironically, as the anthropologist Esra Özyürek mentioned to me, Germans think that in Israel they are replacing El-Hassan as an out-of-place Palestinian native with real natives of the land, Jews, who should also have belonged to Germany had Germans not perpetrated the Holocaust. But in the present context there 
is no land for this native to go to: it is all taken. So in the official German frame, Nemi El-Hassan is uprooted anywhere she goes. How and why does this complex operation take place? Why this zero-sum calculus?

\section{Atonement as Asymmetrical Empathy}

In the first place, much of the German political class around 2000 interpreted the Federal Republic as representing the culmination of humanitarian history. Whether in the realm of refugee policy, foreign aid, environmentalism, or international law, the German political class thinks it embodies the cosmopolitan traditions that the Nazis negated. As Daniela Janser detailed in a perceptive analysis, the German political class is united in believing that the country has a special responsibility to the State of Israel, which it regards not as a regional superpower that is occupying and oppressing another people, but as a precarious refuge for Holocaust survivors requiring its support. The terrible history of the Holocaust weighs on these Germans as a burden impelling them to ensure that, this time, they stand on the right side of history, meaning siding with, rather than against, "the Jews." In doing so, "the Jews" refers to Jews in Germany and in Israel: as a single people occupying a single emotional-political space, detailed in the next subsection.

This atonement-via-universalism fable has a particular entailment, however, which unravels the historical and moral conceit: when the Palestinian presence in Germany disturbs the tidy exchange between the descendants of German perpetrators and Jewish victims. In order to remove these disturbants, Germans engage in asymmetrical empathy. Antisemitism is now ascribed primarily to Muslim migrants while the investigation of anti-migrant violence by native Germans, including systematic murders, is deprioritized. Seemingly mastered, historical trauma is diverted into system-stabilizing channels.

In her ethnographic study of Muslim engagements with the Holocaust, Esra Özyürek has shown that when migrants and their offspring identify themselves with the victims and display emotions, like fear rather than remorse, during Holocaust education, they are accused of lacking empathy with the Jewish victims. By assuming that the only way to engage with the Jewish victims is to internalize the German perpetrator subjectivity, memory culture excludes migrant German individuals from the narrative of becoming democrats through remorse and atonement.

Paradoxically, the German public holds both positions, the one of the historical perpetrator and the hidden helper, as the anthropologist Sultan Doughan describes in 
her field notes. In the educational moments in which contemporary European Muslims recognize a resemblance between themselves and the represented European Jewish communities, Muslims are discouraged from such a relativizing comparison. Rather, they are seen as destroyers and disturbers of an ever-progressing line from the Holocaust to German liberal democracy.

\section{A Single Emotional-Political Space}

This loyalty indicates that Israel and Germany constitute a single emotional-political space, irrespective of distinct sovereignties, legal orders, and values. I adapt this notion from the American Studies scholar and historian, Nikhil Pal Singh. In 2020, he observed that the US and Israel exceeded their vaunted "special relationship" to constitute "a single political community," constituted by shared perceived threats to their settler colonial foundation and a shared resistance to decolonization.

An even more intense mutual identification is observable in the case of Germany and Israel. The journalist Claudius Seidl encapsulated the relationship in writing that "Man bewohnt jedenfalls als Deutscher einen gemeinsamen Geschichts- und Erinnerungsraum mit den Nachkommen der Opfer und Überlebenden" ("In any case, as a German, you live in a common space of history and memory with the descendants of the victims and survivors," emphasis added). That is why Felix Klein, the Federal Commissioner for Jewish Life in Germany and the Fight Against Antisemitism, declares that "youth with migration background" can attest to their integration by accepting Germany's guarantee of Israeli's right to exist as the country's Staatsräson (reason of state), and in adopting Israel's understanding of its foundation: "There needs to be increased education about the foundation of the state of Israel, about the special relationship that Germany has to Israel ... and also perhaps that one can make it clear to them that it makes a good impression if they follow this - as a sign of the willingness to integrate." It also means that anyone chanting "Palestine should be free from the river to the sea" is engaging in antisemitism by questioning Israel's right of existence; such persons are imperiling their status in Germany.

This means nothing less than requiring of Palestinians that they deny an injustice was committed in their mass expulsion, dispossession, the blocking of return, and their statelessness. The historian Ussama Makdisi is thus quite right to observe that Germany's Staatsräson in guaranteeing the security of Israel effectively means guaranteeing the oppression of Palestinians - whether in Palestine, Israel, or in Germany. 


\section{Conclusion}

Not all Germans agreed with Nemi El-Hassan's treatment by Bild-Zeitung, WDR, and the majority of journalists. Marion Detjen, for example, was appalled that El-Hassan would not be allowed to serve as role model for migrants, and indeed that she now represented the fact "that entire populations were, are, and should remain excluded because of their memories and identities." Detjen understood the nature of the transaction: "In Germany, your voice and your face are only welcomed if you not only completely deny your origins, but also serve as a key witness against them." The great tragedy in the affair, she argued, was that El-Hassan was being denied the chance to ascend from her narrow Palestinian particularity, which was, she implied, traumatically retarded and thus suffused with the hate and antisemitism of the Palestinian liberation movement. To be sure, Detjen continued, the learning process should be mutual, as Germans inform themselves about middle eastern history. But her understanding of the region is so suffused with the Orientalism of the flawed universalism characteristic of German public debate that it offers no path beyond the official German frame.

By contrast, some Israelis appreciated the Palestinian structure of experience in its alterity. For example, the leftist Israeli journalist Gideon Levy understood the justice of Palestinian resistance to Zionist colonization. He called the escaped prisoners "freedom fighters" notwithstanding their deeds. "The six defiant ones chose the path of brutal and violent resistance to the occupation. One can argue about its effectiveness against the strong and well-armed Israeli state, but its justness cannot be questioned. They have the right to use violence to resist an occupation that is crueler and more violent than any Palestinian terror." This is a perspective that most Germans are unable to entertain, still less imagine, because they cannot be incorporated into the German frame without creating cognitive dissonance.

WDR ignored such voices, because they do not express what the German political class thinks authentic Jews must believe, represented by the Israeli state and official German-Jewish organizations. Germans' redemptive aligning with the state of Israel leads not only to asymmetrical empathy at the expense of Palestinians. Its conflation of Zionism and Jews also marks non-Zionist Jews and Israelis in Germany as cultural and political enemies. Given the intensity of the German investment in its atonement narrative, it is difficult to foresee the end of affective colonization policies. 


\section{Citations}

1. Moses, A. D. (2007). German intellectuals and the Nazi past / A. Dirk Moses. [electronic resource]. German intellectuals and the Nazi past. Cambridge: Cambridge University Press. $\_$

2. Stoler, A. L. (2007). Affective States. In A Companion to the Anthropology of Politics (pp. 4-20). Oxford, UK: Blackwell Publishing Ltd. $\_$

3. Goffman, E. (1981). Forms of talk / Erving Goffman. Forms of talk. Philadelphia: Univ. of Pennsylvania Press. $\_$ 